\title{
Hvordan analysere sociale differentieringer?
}

\section{Af Sune Qvortrup Jensen}

\section{Analysen af intersektionalitet ma} vare $i$ stand til ikke alene at forstä, bvordan social praksis er struktureret af en rakke forskellige sociale differentieringsformer, men ogsai at disse hver isar har saivel materielle som sociokulturelle dimensioner.

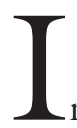

ntersektionalitetsbegrebet har sin væsentligste berettigelse i dets sensitiverende fordring om en systematisk overvejelse af flere forskellige former for sociale differentieringers - eller forskelssættende kategoriers - måde at virke sammen på. I den hidtidige danske anvendelse og udvikling af begrebet om intersektionalitet har især poststrukturalistiske læsninger spillet en stor rolle (Kofoed 2005, Søndergaard 2005, Staunæs 2003 og 2004). Formålet med denne artikel er at foretage en problematiserende, men også anerkendende, diskussion af denne reception af intersektionalitet. Jeg argumenterer fra en sociologisk position, der er inspireret af Bourdieus og Durkheims sociologi. Durkheim (1972) viser i sine tidlige værker, hvordan det sociale har en form for realitet, mens Bourdieu bidrager til begrebsliggørelse af forholdet mellem det materielle og det sociokulturelle (Bourdieu 1999b, Bourdieu \& Wacquant 1996).

Betragtet fra denne position rummer den 
poststrukturalistiske drejning af intersektionalitetsanalyser blandt forskere i Danmark to problemer: For det forste kommer det materielle let til at blive opfattet som en konsekvens af eller en anden form for det diskursive. For det andet kan der ligge en tendentiel ensliggørelse af sociale differentieringsformer, der måske snarere bør opfattes som forskellige. Dette hænger sammen med, at kategorierne tænkes som arbitrære størrelser, der fungerer i kraft af sociokulturelle imperativer.

Jeg illustrerer disse pointer ved at introducere arbejder af henholdsvis Wacquant (1999) og Bourgeois (1995), der begge viser det komplekse samspil mellem flere forskellige former for sociale differentieringer. Begge studier illustrerer, hvordan der konstrueres særlige former for maskulinitet i spændingsfeltet mellem forståelser af køn, seksualitet med videre på den ene side og fraver af konkrete sociale privilegier på den anden. Dermed viser de, at intersektionalitet både handler om aktørernes sociokulturelle forståelser og konkret materiel.

\section{INTERSEKTIONALITET SOM POSTSTRUKTURALISME}

'Intersektionalitet' har ikke en egentlig teoretisk kerne, men må snarere betegnes som en samlende idé, eller som nævnt et sensitiverende eller tentativt begreb. Det er derfor svært at sige noget entydigt om, hvad begrebet indeholder, men lettere at sige noget om, hvordan forskellige forfattere har indholdsudfyldt det. I en dansk kontekst er begrebet først og fremmest blevet indholdsudfyldt af forskere, der arbejder indenfor humaniora med udgangspunkt i poststrukturalistiske strømninger (Kofoed 2005, Søndergaard 2005, Staunæs 2003 og 2004). I det følgende tager jeg derfor afsæt i en diskussion af denne måde at arbejde med intersektionalitet på, dog primært med udgangspunkt i Staunæs' arbejder, idet de formentlig hidtil har haft størst gennemslagskraft i den danske diskussion. Helt overordnet betragter jeg forskellige måder at forstå, teoretisere og operationalisere intersektionalitet på som komplementære frem for gensidigt udelukkende. Ganske vist står poststrukturalisme ikke i et modsætningsforhold til sociologien, idet den snarere er en intellektuel strømning, der går på tværs af fagligheder. Jeg vover alligevel den påstand, at sociologer formentlig vil være tilbøjelige til at begrebsliggøre social differentiering på en anderledes måde end forskere indenfor humaniora.

Den danske reception af begrebet om intersektionalitet er hidtil, som nævnt, primært blevet tegnet af forskere fra de humanistiske fagdiscipliner (med den modifikation, at de nævnte forskere overvejende er psykologer). Interessen hos dem har især været at komme tæe på betydningsdannelser på subjektniveau og indkredse komplekse lokale subjektiveringsprocesser. Staunæs (2004, 30) studerer eksempelvis "hvordan køn og etnicitet bliver til i skolen hver dag som en del af de tolkningsrammer, skolens aktører forstår sig selv og hinanden igennem". Det vil sige, hvordan køn og etnicitet bliver til, leves, gøres og citeres, dvs. opnår eksistens gennem gentagelse (Staunæs 2003, 2004). I Staunæs' aftapning bliver intersektionalitetsanalysen til en indsigtsfuld aflæsning af komplekse netværk af underdeterminerende og underkommunikerede forventninger, normativiteter og imperativer om, hvordan køn, etnicitet og race gøres i specifikke situerede sammenhænge. Denne af- eller udlæsning finder sted gennem observation af menneskelige interaktioner i konkrete kontekster, men det er egentlig ikke de handlende aktørers intentioner - eller i subjektfilosofisk forstand mennesker, (Staunæs 2004, 90) - som forskningsinteressen retter sig mod, og den er derfor frisat fra eksistentialistisk og hermeneutisk/fænomenologisk tænkningl (se også Järvinen og Mik-Meyer, 2005).

Som jeg forstår Staunæs, analyserer hun intersektionalitet som noget, der primært foregår inden for et sociokulturelt rum. 
Dette rum er udspændt af diskursive strukturerende principper, der begrebsliggøres som imperativer og normativiteter. Dermed er det ikke voluntaristisk. 'Skævgørelser', som er Staunæs' ord for ikke-konform praksis, mødes således med sociale sanktioner.

Staunæs' intersektionalitetsreception er altså overvejende sociokulturel. Samtidig abonnerer Staunæs på en dekonstruktivistisk forståelse af videnskab, og hendes hensigt er at skubbe til størknede og fastfrosne kategorier. Denne reception af begrebet om intersektionalitet har produceret tre vigtige principper: For det forste princippet om ikke a priori at give nogen kategorier primat; for det andet det majoritetsinkluderende princip om at inddrage det umarkerede center $\mathrm{i}$ analysen og ikke lade det forblive neutralt (mænd som kønnede, danskere som etniske med videre); for det tredje det ikke-additive princip, at forskellige kategorier virker og i princippet skal analyseres på samme tid. Dette tredje princip er det mest interessante og kontroversielle ved intersektionalitetsbegrebet, idet man med Kofoed $(2005,44)$ kan påpege, at "kategorier kan overdrive hinanden eller underkende hinanden eller endda ophæve hinanden".

Dette poststrukturalistiske og dekonstruktivistiske bidrag er vigtigt, men man kan også gå andre veje i en videreudvikling af intersektionalitet. De los Reyes \& Mulinari (2005) nævner eksempelvis antiracistisk og marxistisk teori som inspirationsgrundlag, intersektionalitetsanalysen bør tænkes i dialog med (se også Lykke 2003).

Samstemmende pointerer McCall (2005), at intersektionalitetsbegrebet har en række temmelig forskellige teorihistoriske ophav. Således er sorte feministers tidlige kritik af hvid, heteroseksuel, middelklasse- og mainstreamfeminisme senere konvergeret med en ganske betydningsfuld indflydelse fra nyere især fransk (social)filosofi dekonstruktivisme og poststrukturalisme. Herved ændres fokus fra et argument om, at flere forskellige kategorier må tages i be- tragtning, hvis samfundsmæssige underordnings- og magtmekanismer skal forstås, til et fokus, der dekonstruerer eller destabiliserer kategorierne. I stedet for at bringe flere forskellige kategorier i spil, for at udvikle en mere nuanceret forståelse af forskellige magtasymmetriers og ulighedssystemers samvirke, bringes kategorierne så at sige i spil med henblik på at destabilisere hinanden gensidigt. I tidlige standardreferencer, som Crenshaws Mapping the margins (1994), er fokus således på, hvordan hvid middelklasse feminisme tendentielt marginaliserer etnisk-racialiserede, socialt og økonomisk ikke-privilegerede kvinder. Dette indebærer en antiracistisk kritik af en universalistisk forståelse af kvinder som gruppe, men bestræbelsen går nærmere på at specificere, nuancere og skærpe en social kritik, end at dekonstruere eller destabilisere kategorierne kvinde og sort ${ }^{2}$ (se også Mulinari og de los Reyos 2005, 15, Crenshaw 1989, Hill Collins 1994 og 2000). Et sociologisk bidrag kunne være at opfatte køn, klasse, etnicitet og 'race' som teoretisk set reelle sociale differentieringsformer, der har det til fælles, at de alle har både sociokulturelle og materielle dimensioner, men herudover fungerer efter forskellige logikker. ${ }^{3}$

\section{SOCIOLOGISKE KUNDSKABSTILBUD FRA DEN SOCIALE VERDENS SKYGGESIDER}

Foreløbig har min kritiske diskussion af den poststrukturalistiske forskning i intersektionalitet været teoretisk. Jeg vil nu forsøge at eksemplificere pointen om at gribe relationen mellem det materielle og det sociokulturelle ved at trække på to studier fra et mandligt socialt univers. Studierne analyserer intersektionalitet blandt etnisk-racialt minoriserede og socio- $\varnothing$ konomisk underprivilegerede mænd i amerikanske storbyer: Philippe Bourgeois $(1995,1996)$ undersøger Puertoricanske cracksælgere i El Barrio, og Loïc Wacquant (1999) undersøger sorte boksere i Chicago. Begge analyser er funderet i teoretisk informeret empirisk arbejde i specifik- 
ke lokaliteter. De fokuserer på såvel det socio-kulturelle, som det materielle i forhold til differentieringsformer som køn, klasse, etnicitet, race og seksualitet.

Philippe Bourgeois (1995, 1996) analyserer unge voksne kriminelle puertoricanske mænd i New York. Disse unge mænd er etnisk-racialt minoriserede. Til dette føjer sig problemer af klassemæssig karakter. Forskydninger i den politiske økonomi medfører forandringer i erhvervsstrukturen, og dermed en svigtende efterspørgsel efter 'maskulin', styrkebetonet ufaglært arbejdskraft. De industrielle arbejdspladser forsvinder og tilbage bliver et arbejdsmarked, som primært består af ufaglærte jobs i servicesektoren. Da disse unge mænd ikke har nævneværdig uddannelse, har de ikke mulighed for at være opadgående mobile. De har yderligere det problem, at servicesektoren især efterspørger kvindelig arbejdskraft. Endelig er en tilværelse som lavtlønsarbejder i ufaglærte jobs i servicesektoren svært forenelig med deres sociokulturelle opfattelser af maskulinitet. Deres maskuline stolthed er knyttet til en forestilling om 'the male breadwinner' og konkret hårdt fysisk arbejde, en forestilling der kan føres tilbage til den særlige Jibaro livsform i sukkerrørsplantagerne i Puerto Rico. Denne forestilling ligger som et sociokulturelt tolkningsrepertoire, der aktiveres under visse betingelser. Som en kombination af sociokulturelle og materielle forhold bliver de unge mænd derfor marginaliserede i en ret håbløs social situation.

Mændene bliver i økonomisk forstand relativt dårligere stillet end de unge kvinder i samme bydel, der har bedre erhvervsmuligheder i servicesektoren. De unge mænd bliver $\mathrm{i}$ nogen grad tvunget til at leve af kvindernes indkomster, og bliver dermed underordnet kvinderne økonomisk. I et vist omfang udmønter disse relationer sig i en uerkendt sammenblanding af økonomisk asymmetri på den ene side og seksuel og følelsesmæssig afhængighed, magt og udnyttelse på den anden.
Som en reaktion på og bearbejdning af dette asymmetriske seksuelle og økonomiske bytteforhold udvikler de unge mænd stærkt sexistiske og stereotype holdninger til kvinder og seksualitet. Sexismen kan forstås som en i en vis forstand nødvendig dimension i den etnisk-racialiserede og klassespecifikke maskulinitetsform, disse unge mænd indstifter som en del af deres gadekultur. Den er nødvendig i den forstand, at de unge mænd kan påberåbe sig en maskulinitet og seksuelle præstationer i deres $s \varnothing$ gen efter respekt i en social situation, hvor de ellers ikke har meget at påberåbe sig.

Loic Wacquants (1999) studie af sorte boksere i Chicago viser, hvordan den håbløse socio-økonomiske situation blandt disse sorte mænd, påvirker deres måde at gøre køn og seksualitet på. Uden fast indkomst bliver en vigtig del af deres overlevelsesstrategi, at de indgår i seksuelt intime relationer til kvinder, som samtidig giver dem penge, mad og husly. Kvinderne får nærhed, omsorg og intimitet, og mændene får penge. Som en måde at forsvare deres maskuline ære på, og konstruere et positivt selvbillede på, opfatter de sig som seksuelt attraktive 'hustlere'. Samtidig benægter de konstant deres økonomiske livsvilkår, idet de lever på en forestilling om, at de står lige over for et gennembrud som professionelle boksere.

Bourgois' og Wacquants analyser viser, at materiel fattigdom rammer på en klassespecifik måde, som imidlertid får særligt barske konsekvenser for etniske minoriteter og sorte. Samtidig kommer denne fattigdom til at ramme kvinder og mænd forskelligt. Især Bourgeois kredser om, hvordan der hos mændene aktiveres sociokulturelle fortolkningsrepertoirer, som de bruger til at tolke situationen og forstå sig selv ud fra. Disse tolkningsrepertoirer kombineres med en allerede eksisterende amerikansk storbyog gadekultur og resultatet bliver en form for hybrid subkultur. De unge mænd skaber altså, under påvirkning af deres sociale situation, en subkultur, hvori en særlig type 
maskulinitet virker som et alternativt kriterium for anerkendelse. Dette sker på både kvinders mændenes egen bekostning, idet det resulterer $\mathrm{i}$ en $\emptyset$ get vold både mod kvinder og mellem mænd. På den måde illustrerer de to forfatteres studier, at materielle xndringer spiller sammen med sociokulturelle tolkningsrepertoirer på en sådan måde, at hele sammenfiltreringen af køn, klasse, etnicitet, race og seksualitet forskubbes.

\section{EN ONTOLOGISK SOCIOLOGISK TEORI OM KØN SOM SOCIAL DIFFERENTIERING}

I den poststrukturalistiske forståelse af intersektionalitet omtales køn, klasse, etnicitet og 'race' som kategorier (Kofoed 2005, Søndergaard 2005, Staunæs 2003, 2004, 2005, se også Mørck 2005). Denne måde at tale om eksempelvis køn på har flere betydninger: For det forste positionerer man sig væk fra en positivistisk eller naivt realistisk tale om 'variable' (Se for eksempel Staunæs 2004, 59-61). For det andet markeres det, at man analyserer menneskers magtfulde måde at kategorisere hinanden på. Køn er noget man i en diskursiv, sociokulturel og principielt arbitrær proces kategoriseres som, hverves til, og derfor gør, ikke noget man er.

Kategorierne har således baggrund i diskursive og sociokulturelle forståelser, som deles i et samfund eller dele af et samfund og ikke i nogen ontologisk realitet. Som sådan kan køn nærmest betragtes som en reificeret social fantasme. Opfattelsen af køn og andre forskelssættende kategorier som i princippet arbitrære diskursive kategorier er et meget væsentligt bidrag til kønsforskningen, men en indvending kunne være, at den er bedre til at tænke i konformitetspres end til at begribe konkret ulighed.

Et supplerende sociologisk bidrag kunne være at tænke køn, klasse, etnictet og 'race', som grundlæggende sociale differentieringsformer, der har en realitet eller fakticitet, og dermed en form for ontologisk sta- tus. I en sådan tænkning opfattes køn, klasse, etnicitet og race ikke som arbitrære eller ontologisk tomme kategorier, men derimod som termer, der strejfer reelle sociale differentieringsformer. Køn kan altså anskues som noget $\mathrm{i}$ en vis forstand reelt, ikke i biologisk eller essentialistisk forstand, men som en reelt eksisterende social differentieringsform, der ikke kan teoretiseres som primært diskursiv eller sociokulturel, selvom kønnet nødvendigvis også skal tænkes diskursivt og sociokulturelt. Man kunne udtrykke det på den måde, at køn er noget kulturligt (i betydningen ikke naturligt eller biologisk), men samtidig at køn som social differentieringsform har en realitet, som handler om andet end diskurser, normativiteter og imperativer. Forstået som social differentieringsform har køn en form for ontologisk status.

Inspireret af Butler (1990, 1993) indskriver de nævnte danske intersektionalitetsbidrag sig samtidig i den forståelse, at kønnet så at sige skabes i handlingen. Det er den gentagne gørelse (citation) af køn, der konstituerer det kønnede subjekt - ikke omvendt. Det betyder, at kønnet er en konsekvens af, eller et produkt af, interaktionen, og at der altså teoretisk og logisk ikke er noget kønnet subjekt forud for gørelsen af køn. Hvis vi omvendt vælger at tænke på køn som en grundlæggende social differentieringsform findes køn både før og efter gørelsen (citationen), og kønnet strukturerer på den ene side interaktionen, samtidig med at køn på den anden side også reproduceres - eller måske bedre medproduceres - i sociale interaktioner. Køn, klasse, etnicitet og 'race' kan dermed betragtes som sociale fakta i Durkheims forstand. Det vil sige forhold, der har deres årsag i det sociale og findes uafhængigt af deres individuelle manifestationer (Durkheim 1972). Som sådan er køn noget helt grundlæggende og konstituerende for samfundet. Forfølges denne tankerække kan man diskutere opfattelsen af køn, som resultat af uendelig mange gentagne hverdagslige cita- 
tioner. Køn er en diskursiv kategori, der gøres eller tales i eksistens, men er samtidig mere og andet end det.

\section{OM DET MATERIELLE OG DET DISKURSIVE}

Jeg har ovenfor foreslået, at de poststrukturalistiske strømninger, som den hidtidige danske reception af intersektionalitet overvejende har baseret sig på, kan medføre det diskursives primat, således at det materielle underordnes det diskursive eller teoretiseres som en konsekvens af det diskursive. Dette problem er alment for poststrukturalismen, men får specifikke konsekvenser for poststrukturalistiske anvendelser af dette begreb. Men hvordan håndteres det materielle i den poststrukturalistiske intersektionalitetsreception i Danmark? Hos Staunæs, kan man spore tre delvis overlappende måder at forholde sig til det materielle på. Staunæs opererer med et begreb om diskursiv materialitet, som bærer to betydninger. For det første at det materielle kan opfattes som en anden type diskurs. Med henvisning til Butler skriver Staunæs således, at et hus blandt andet kan forstås som "et udtryk, et tegn, et diskursivt indlæg om, hvem beboerne er, og hvad huse kan være" $(2004,103)$. For det andet, at det materielle er en konsekvens af det diskursive, at der ligger ideer og diskurser bag det materielle, og at det diskursive derfor kommer først - om ikke historisk så i hvert fald logisk teoretisk. I forlængelse heraf analyserer Staunæs for det tredje, hvordan den konkrete arkitektoniske og bygningsmæssige indretning af de skoler hun undersøger, kan læses som en diskursiv materialitet, der muliggør og sandsynliggør visse subjektiveringstilbud og gør andre smertelige, umulige eller i hvert fald besværlige.

Denne analyse er i sig selv relevant og nødvendig. Men at se på materialitet i form af overordnede sociale differentieringsformers materielle dimension ville have indebåret et blik, der rækker ud over skolekonteksten og orienterer sig mod de konkrete livsvilkår, som forskellige elevsubjekter er rundet af.

Man kan således argumentere for, at analyser af intersektionalitet må søge at begribe de grundlæggende sociale differentieringsformers ikke-diskursive dimensioner.

For at gennemføre dette argument er det imidlertid nødvendigt at se lidt på, hvordan man kan teoretisere materialitet $\mathrm{i}$ et socialkonstruktivistisk kønsforskningsfelt. For at forklare forskellen er det hensigtsmæssigt at skelne mellem ontologisk og epistemologisk konstruktivisme. Ved epistemologisk konstruktivisme forstår jeg den videnskabsteoretiske indsigt, at vi som mennesker aldrig kan have nogen direkte udveksling med virkeligheden. Snarere filtreres vores erkendelse af verden altid gennem sociokulturelle, diskursive, teoretiske, præteoretiske eller hverdagslige forestillinger om verden. Viden er derfor noget, der produceres og konstrueres aktivt, frem for noget der ligger ude $i$ verden og venter på at blive opdaget. I dag vil de fleste inden for kønsforskningen vel tilslutte sig denne pointe med større eller mindre forbehold. Ved ontologisk konstruktivisme forstår jeg den opfattelse, at den sociale verden består af diskursive sociale konstruktioner, og at det, der sker i den sociale verden, er en konsekvens af eller er struktureret af sociale konstruktioner af diskursiv karakter. Eftersom vores opfattelse af virkeligheden er socialt og diskursivt konstrueret, hævdes den sociale virkelighed således $i$ sidste instans at bestå af diskursive sociale konstruktioner og deres konsekvenser.

Med denne skelnen i baghovedet er det muligt at overveje, hvorvidt ontologisk konstruktivisme nødvendigvis er en logisk konsekvens af epistemologisk konstruktivisme. Jeg antager, at det diskursive er en forudsætning for menneskelig erkendelse af verden, men også at man af epistemologiske overvejelser om grundlæggende præmisser for menneskelig erkendelse ikke kan aflede en ontologi eller teori om verden.

Bech (2005, 68-69) skelner på omtrent tilsvarende vis mellem socialkonstruktivis- 
me og diskurskonstruktivisme, ligesom andre forfattere skelner mellem forskellige socialkonstruktivismer (Järvinen \& Bertilsson 1998, Wenneberg 2002). Med udgangspunkt i socialkonstruktivisme som epistemologi, er det stadig muligt at operere med en teoretisk præmis om at sociale differentieringsformer har materielle dimensioner, som kun er løst koblet til, og dermed relativt uafhængige af de sociokulturelle eller diskursive dimensioner ved disse differentieringsformer.

Konstruktivistisk epistemologi udelukker således ikke antagelsen om det materielles ikke-diskursive eksistens, forstået som et redskab, man bruger til at konstruere sin forskningsgenstand med og betragte verden ud fra. Floya Anthias (2001) har i den forbindelse givet et væsentligt bidrag til diskussionen om forholdet mellem sociale differentieringsformers diskursive og materielle dimensioner. ${ }^{4}$ Anthias pointerer, at det er problematisk at opfatte køn som noget, der først og fremmest er af diskursiv eller sociokulturel karakter, hvorimod klasse opfattes som en differentieringsform, der først og fremmest er relateret til det materielle: "Within most approaches to stratification gender and ethnicity are seen to pertain primarily to the symbolic or cultural realms, whilst class is regarded as pertaining to material inequality....." (2001, 267). Med Anthias vil jeg påpege, at både køn og klasse, etnicitet og 'race' har såvel diskursive som materielle dimensioner, og således undgå "[the] idea of the analytical distinctions between social divisions being constituted via difference between material reality on the one hand, and the cultural and symbolic realm on the other" (ibid. 378).

Konsekvensen af dette synspunkt er at opfatte såvel køn, klasse etnicitet og 'race' som grundlæggende sociale differentieringsformer, der alle har såvel diskursive som materielle dimensioner.

Hvis man vil forstå de materielle dimensioner af køn som social differentieringsform, kan man således tænke på uligeløn, lønarbejdets kønsarbejdsdeling eller den ulige fordeling af husarbejde. Disse materielle forhold er selvsagt txt knyttet til diskurser og forestillinger, men det betyder ikke, at de nødvendigvis bør teoretiseres som konsekvenser af det sociokulturelle. På den anden side er analyser, der opfatter diskurser og ideer som irrelevante overfladefænomener åbenlyst utilfredsstillende. Således antager jeg, at det materielle ikke determinerer det diskursive, eller at det materielle ikke kan teoretiseres som afledt af det diskursive. Snarere end en homologi mellem sociale differentieringsformers materielle og sociokulturelle dimensioner er der tale om en underdetermineret, heterolog eller løst koblet relation uden entydig årsagsretning.

I intersektionalitetsforskningen kan det være hensigtsmæssigt analytisk at adskille det materielle og det sociokulturelle netop for at kunne analysere denne relation. Denne skelnen mellem materielle og diskursive dimensioner er således vigtig, fordi den medfører en udfordring om at gribe og begribe sammenhængen mellem de sociale differentieringsformers materielle og sociokulturelle dimensioner.

Ovenstående har således konsekvenser for, hvordan vi overhovedet kan tænke og teoretisere intersektionalitet. Selv om poststrukturalistiske analyser af intersektionalitet allerede er meget komplicerede, er de i en vis forstand ikke komplicerede nok. En sociologisk udfordring til analysen af intersektionalitet kunne således være, ikke alene at begribe flere forskellige sociale differentieringsformer samtidig, men også at udvikle forståelser, der sætter os i stand til at begribe den ikke-reducerbare relation mellem det materielle på den ene side og det diskursive eller sociokulturelle på den anden side. Analyser af intersektionalitet må derfor fordobles, idet den må være i stand til ikke alene at forstå, hvordan social praksis er struktureret af en række forskellige sociale differentieringsformer, men samtidig at disse hver især har såvel materielle som sociokulturelle dimensioner. 


\section{VÆSENSFORSKELLIGE}

\section{DIFFERENTIERINGSFORMER}

Jeg har ovenfor foreslået, at den poststrukturalistiske drejning af intersektionalitet som analytisk perspektiv kan tendere til at ensliggøre forskellige former for social differentiering. Dette er et alment problem i poststrukturalismen, men især uhensigtsmæssigt $\mathrm{i}$ analyser af intersektionalitet, fordi det netop her er vigtigt at begribe og teoretisere differentieringsformerne i deres specificitet. Denne ensliggørelse skyldes den stærke betoning af, at køn, klasse, etnicitet og 'race' i princippet er arbitrære diskursive kategorier uden ontologisk status. Når eksempelvis køn således tænkes som en tom og arbitrær, men magtfuld og forskelssættende kategori - en konsekvens af en gentagen citeren - bliver der ikke nogen ontologisk specificikt at analysere. Denne problematik er sat på spidsen i West \& Fenstermakers bog, Doing difference:

Despite many important differences in the histories, traditions, and varying impacts of racial and sexual oppression across particular situations, the underlying mechanism is the same. To the extent that members of society know their actions are accountable, they will design their actions in relation to how they might be seen and described by others. (West \& Fenstermaker 1995, 25. Min fremhævning)

West og Fenstermakers fremfører, at køn og 'race' fungerer efter de samme mekanismer. Af konteksten fremgår yderligere, at klasse fungerer efter samme logik. En sociologisk indvending kunne være, at en intersektionalitetsanalyse inspireret af West og Fenstermaker meget let kommer til at ensliggøre forskellige sociale differentieringsmekanismer, fordi doing-tænkningen reducerer de komplekse logikker i grundlæggende sociale differentieringsformer som køn, klasse, etnicitet og 'race' til den samme logik, nemlig dén at afstemme handlinger efter omgivelsernes forventninger. Hermed reduceres analysen til en aflæsning af, hvordan mennesker gør, forhandler eller udfordrer omgivelsernes normative forventninger til, hvordan man gør kategorierne.

Hvis man følger dette argument, er det en vigtig påpegning, at de forskellige grundlæggende sociale differentieringsformer alle har en dimension, der kan ses som konformitetspres, men derudover er de forskellige og fungerer efter forskellige logikker. Det falder uden for denne artikels ramme at afsøge, hvordan de forskellige differentieringsformer hver især fungerer, men man kan tentativt skitsere en illustrativ forskel. For eksempel er der kvinder og mænd i alle klasser, mens klasserne i sig selv lever relativt adskilt fra hinanden. Der er også kvinder og mænd i alle etniske grupper, mens etniske grupper lever relativt adskilt. Etnicitet og klasse fungerer altså $\mathrm{i}$ henhold til segregerende logikker på en ret gennemgribende måde, mens køn blot har segregerende virkninger på nogle livsområder (for eksempel arbejdsmarkedssegregering). Køn fungerer rumligt anderledes end klasse og etnicitet. Differentieringsformerne har også forskellig historie. Derfor må man konsultere forskellige specifikke teorier, når man vil vide noget om køn, klasse, etnicitet eller race.

Sammenfattede har en række væsentlige sociale differentieringsformer den egenskab til fælles, at de alle har både materielle og diskursive dimensioner, men derudover fungerer de på forskellige måder og i henhold til forskellige logikker. I analyser af intersektionalitet er det derfor vigtigt at begribe sociale differentieringsformer i deres specificitet og undgå at reducere dem til samme logik.

\section{AFrUNDING}

Intersektionalitetsbegrebet er relativt nyt $\mathrm{i}$ dansk kønsforskning. Ikke desto mindre har begrebet hurtigt fået en udbredelse, der i sig selv kunne tyde på, at det griber noget væsentligt. Det er derfor relevant at afsøge 
og udfolde forskellige måder at analysere intersektionalitet på, og at undersøge hvilke indsigter forskellige tilgange henholdsvis muliggør og udgrænser. Empiriske sociologiske studier af socialt underprivilegerede understreger nødvendigheden af at gribe relationen mellem det sociokulturelle og menneskers konkrete materielle livsvilkår. Det gør det muligt at undersøge forskydninger i de materielle livsvilkår og deres konsekvenser for, hvordan man gør køn, klasse, etnicitet, race og seksualitet. Denne måde kan hverken reduceres til, på den ene side den determinerende kraft i materielle livsomstændigheder eller på den anden side gørelser og forhandlinger af sociokulturelle imperativer og normativiteter.

Et af sociologiens bidrag til den nuværende danske intersektionalitetsdebat kunne således være at pege på nødvendigheden af at give konkrete materielle uligheder mere opmærksomhed i analyserne, samt at påpege, at forskellige sociale differentieringsformer måske fungerer på ganske forskellige måder.

\section{NOTER}

1. Staunæs diskuterer og forkaster således Søndergårds begreb om randpersoner til fordel for sit eget begreb om grænsefigurer: "“Person” konnoterer moderne psykologiserende individualiserende begreber, hvorimod "figur" konnoterer karakter uden personlighed, der viser forklarende hen til eller illustreret noget i verden" (Staunæs 2004, 69). 2. McCall argumenterer således for at fastholde udvalgte kategorier og bruge dem som strategiske anchorpoints for sammenligning mellem grupper (2005).

3 . Derudover er de her behandlede sociale differentieringsformer alle hierarkiske, men en dybere behandling af dette forhold falder uden for nærværende artikels rammer.

4. Anthias bruger gennemgående termen symbolsk på samme måde, som man ofte ville bruge diskursiv. Forskellen på de to termer er irrelevant for nærværende diskussion.

\section{LITTERATUR}

. Anthias, Floya (2001): "The material and the symbolic in theorizing social stratification: issues of gender, ethnicity and class", in The British Journal of Sociology 2001/3.

- Bech, Henning (2005) Kvinder og mand. Hans Reitzels Forlag.

- Bourdieu, Pierre et al. (1999a) The Weight of the world: Social Suffering in Contemporary Society. Cambridge: Polity Press.

- Bourdieu Pierre (1999b) Meditasjoner. Pax forlag. - Bourdieu, Pierre \& Loïc Wacquant (1996): Refleksiv Sociologi. Hans Reitzels Forlag - Bourgois, Philippe (1996) "In Search of Masculinity", in British Journal of Criminology 1996/3.

- Bourgeois, Philippe (1995) In Search of Respectselling crack in El Barrio. Cambridge University Press.

- Butler, Judith (1993) Bodies that matter: on the discursive limits of "sex". Routledge.

- Butler, Judith (1990) Gender trouble: feminism and the subversion of identity. Routledge.

- Callewaert, Staf (1997) Bourdieu-studier. Institut for Filosofi, Pxdagogik og Retorik. Københavns Universitet Amager, København.

. Crenshaw, Kimberle W. (1994) "Mapping the Margins - Intersectionality, Identity Politics and Violence Against Women of Colour", in Martha Finneman \& Rixanne Mykitiuk (eds.) The Public Nature of Private Violence, Routledge.

. Crenshaw, Kimberle W. (1989) "Demarginalizing the Intersection of Race and Sex:" A Black Feminist Critique of Antidiscrimination Doctrine, Feminist Theory and Antiracist Politics.", in University of Chicago Legal Forum, University of Chicago 1989.

- Durkheim, Emile (1972) Den sociologiske metode. Fremad.

- Hill Collins, Patricia (2000) "it's all in the family: Intersections of Gender, Race and Nation", in Uma J. Narayan \& Sandra Harding (eds.): Decentering the center: Philosophy for a multicultural, postcolonial ands feminist world. Indiana University Press.

- Hill Collins, Patricia (1993) "Toward a New Vision: Race, Class and Gender as Categories of Analysis and Connection", in Race, Sex \& Class $1993 / 1$.

· Jensen, Sune Qvotrup (2005) “Mangetydigt skoleliv", in Social Kritik 2005/99 (anmeldelse af Staunæs 2004).

· Järvinen, Margaretha \& Nanna Mik-Meyer (2005) Kvalitative metoder $i$ et interaktionistisk perspektiv. Hans Reitzels forlag. 
· Järvinen, Margaretha \& Margaretha Bertilsson (1998): Socialkonstruktivisme. Bidrag til en kritisk diskussion. Hans Reitzels forlag.

. Kofoed, Jette (2005) "Holddeling: Når der gøres maskulinitet og hvidhed", in Kvinder, Køn \& Forskning 3/05.

. de los Reyes, Paulina \& Mulinari, Diana (2005)

Intersektionalitet. Liber.

. Lykke, Nina (2003) "Intersektionalitet - ett användbart begrepp för genusforskningen", in Kvinnovetenskaplig Tidskrift 2003/ 1.

- McCall, Leslie (2005) "Managing the complexity of intersectionality", in Signs: Journal of Women in Culture and Society 2005/3.

- Mørck, Yvonne (2005) "Intersektionalitet og diversitet - Fadimesagen", in Henning Bech \& Anne Anne Scott Sørensen (red.): Kultur på kryds og tvers. Klim.

- Prieur, Annick (2002) “Objektivering og refleksivitet - om Pierre Bourdieus perspektiv på design og interview", in Michael Hviid Jacobsen, Søren Kristiansen \& Annick Prieur (red.): Liv, Fortalling, Tekst - Strejftog i kvalitativ sociologi. Aalborg Universitetsforlag.

- Staunæs, Dorthe (2005) "Zombies and Clones in Diversity Management", AMID Working Paper Series $2005 / 40$.

- Staunæs, Dorthe (2004) Køn, etnicitet og skoleliv. Samfundslitteratur.

- Staunæs, Dorthe (2003) 'Where have all the subjects gone? Bringing together the concepts of intersectionality and subjectification', in Nora $2003 / 2$.

. Søndergaard, Dorte Marie (2005) "Making Sense of Gender, Age, Power and Disciplinary Position: Intersecting Discourses in the Academy", in Feminism \& Psychology 2005/2.

. Wacquant, Loïc J. D. (1999) "Inside 'The Zone", in Pierre Bourdieu et al. (eds.): The Weight of the World: Social Suffering in Contemporary Society, Cambridge: Polity Press.

- Wenneberg, Søren Barlebo (2002) Socialkonstruktivisme. Samfundslitteratur.

- West, Candace \& Fenstermaker, Sarah (1995)

"Doing difference", in Gender \& Society 1995/1.

\section{SUMMARY}

The current Danish reception of the concept of intersectionality has largely been of a poststructuralist bend. However, the history of the concept is not necessarily as tightly related to poststructuralist theory as often assumed. Although the contributions produced by this reception must be recognised, the poststructuralist version of intersectionality is problematic from a specific sociological position. When social categories are presented as something people do, the reality of social differentiation is downplayed. Poststructuralist thinking rests on an inadequate conception of the material, as this form of thought tends to theorize this as another type of discourse or as a consequence of discourse. It furthermore tends to homogenise the logics underlying different forms of social differentiation. These points are illustrated by the works of Bourgeois and Wacquant where socio-cultural interpretations are transformed by changes on a material level.

Sune Qvotrup Jensen, ph.d.studerende, Institut for Historie, Internationale Studier og Samfundsforhold, Aalborg Universitet 